\title{
Reduction of G Protein-Coupled Receptor Kinase 2 Expression in U-937 Cells Attenuates H2 Histamine Receptor Desensitization and Induces Cell Maturation
}

\author{
NATALIA FERNÁNDEZ, FEDERICO MONCZOR, BIBIANA LEMOS, CINTIA NOTCOVICH, ALBERTO BALDI, \\ CARLOS DAVIO, and CARINA SHAYO
}

National Research Council of Argentina, Buenos Aires, Argentina (N.F., F.M., A.B., C.D., C.S.); Institute of Biology and Experimental Medicine, Buenos Aires, Argentina (N.F., A.B., C.S.); Radioisotopes Laboratory, School of Pharmacy and Biochemistry, University of Buenos Aires, Argentina (N.F., F.M., B.L., C.N., C.D.); and Department of Physiology, Molecular and Cellular Biology, School of Sciences, University of Buenos Aires, Argentina (C.S.).

Received May 14, 2002; accepted September 17, 2002

This article is available online at http://molpharm.aspetjournals.org

\begin{abstract}
Histamine and $\mathrm{H} 2$ agonists transiently induce an important cAMP response in promonocytic $U-937$ cells but fail to induce monocytic differentiation because of a rapid receptor desensitization mediated by $G$ protein-coupled receptor kinases (GRKs). The aims of the present study were to investigate the participation of GRK2 in the desensitization mechanism of the $\mathrm{H} 2$ receptor in $\mathrm{U}-937$ cells by reducing GRK2 levels through antisense technology and to evaluate the differentiating capacity of cells expressing lower GRK2 level, stimulated by $\mathrm{H} 2$ agonists. By stable U-937 cell transfection with a GRK2-antisense cDNA, we obtained D5 and A2 cell clones exhibiting a reduction in GRK2 expression and an $\mathrm{H} 3$ clone with no significant difference in GRK2 expression from control cells. The
\end{abstract}

cAMP response induced by the $\mathrm{H} 2$ agonist in $\mathrm{D} 5$ and $\mathrm{A} 2$ but not in $\mathrm{H} 3$ cells was higher than in U-937 and persisted for a longer period of time, although the number of $\mathrm{H} 2$ receptors in $\mathrm{D} 5$ and A2 cells was lower than in U-937. Furthermore, D5 and A2 cells treated with $\mathrm{H} 2$ agonist showed patterns of C-Fos and CD88 expression consistent with monocytic differentiated cells. Overall, these results indicate a direct correlation between the expression of GRK2 and the desensitization of natively expressed $\mathrm{H} 2$ receptors in U-937 cells, suggesting that GRK2 plays a major role in the regulation of these receptors' response. In turn, desensitization process is a key component of $\mathrm{H} 2$ receptor signaling, determining the differentiation capability of promonocytic cells.
Histamine is a biogenic amine widely distributed throughout the body that works as a chemical messenger to exert numerous functions in central and peripheral tissues, including the induction of normal promyelocytic differentiation (Tasaka et al., 1994). These effects are mediated through three pharmacologically distinct subtypes of receptors, the H1, H2, and H3 receptors (Hill, 1990; Leurs et al., 1995; Hill et al., 1997). Recently, the $\mathrm{H} 4$ receptor was cloned and preliminarily characterized (Zhu et al., 2001). Molecular biology studies indicate that the histamine receptor belongs to the large multigene family of $G$ protein-coupled receptors (GPCRs). Structurally, these receptors are characterized by seven transmembrane $\alpha$-helices and functionally by their

\footnotetext{
This study was supported by grants from the University of Buenos Aire (grant BO22), the Consejo Nacional de Investigaciones Científicas y Tecnológicas, (PID 792/98), the Agencia Nacional de Promoción Científica y Técnológica, (PICT 9805-03514), and the Ministerio de Salud de la Nación Argentina (Carrillo-Oñativia grant).
}

ability to transmit signals to effector molecules via G proteins (Dohlman et al., 1991). GPCRs play key physiological roles and their dysfunction results in several health disorders. The H2 receptor (H2r) causes cAMP accumulation through Gs protein activation in gastric cells, cardiac tissues, and other cell types, including smooth muscle cells and immune cells (Hill, 1990).

For a large number of GPCRs, rapid desensitization seems to involve receptor phosphorylation. $G$ protein-coupled receptor kinases (GRKs) are responsible for homologous desensitization, whereas the second messenger-dependent kinases, protein kinases A (PKA) and C, could be involved in homologous and heterologous desensitization (Freedman and Lefkowitz, 1996; Post et al., 1996; Moffett et al., 2001). GRKmediated phosphorylation of serine/threonine residues in the carboxyl tail and/or intracellular loops of GPCRs increases the receptor affinity to arrestin-type proteins, and this binding prevents any further coupling between the receptor and 
G proteins. The complex formed by the phosphorylated GPCR and arrestin targets the activated receptor to clathrincoated pits for subsequent internalization (Pitcher et al., 1998). There are six members of the GRK family: GRK1 through GRK6. On the basis of sequence homology, these can be classified into three groups: GRK1 (also known as rhodopsin kinase), GRK2 and -3 (also called $\beta$-adrenergic receptor kinases 1 and 2), and, finally, GRK4, -5, and -6. The mechanisms by which GRK activity is regulated can be divided into three categories: subcellular localization, alterations in intrinsic kinase activity, and alterations in GRK expression levels. Cytosolic GRK2 and -3 are translocated to the membrane after receptor activation, in a process facilitated by the interaction with released G $\beta \gamma$ dimers (Palczewski, 1997; Penn et al., 2000). Although GRK2, $-3,-5$, and -6 subtypes are ubiquitous, GRK2 is particularly abundant in peripheral blood leukocytes and in myeloid and lymphoid cell lines (Chuang et al., 1992).

The promonocytic U-937 cell line, derived from a histiocytic lymphoma, is considered an appropriate model to study the mechanism of cell differentiation (Harris and Ralph, 1985). It has been postulated that terminally differentiated cells would progressively lose their malignant capacity. In this cell line, dibutyryl cAMP (dbcAMP) and forskolin [an adenylyl cyclase (AC) activator] induce monocyte maturation (Gavison et al., 1988; Brodsky et al., 1998), whereas histamine-increased cAMP levels via H2r fail to promote differentiation, probably because of the rapid desensitization of the response (Shayo et al., 1997; Lemos Legnazzi et al., 2000). This early desensitization proved to be homologous and to involve receptor phosphorylation by the GRK family. Later, other mechanisms, such as an increase in nucleotide-phosphodiesterase activity or the reduction in receptor number, become involved in the decreased cell response to prolonged H2 agonist stimulation (Lemos Legnazzi et al., 2000).

The molecular mechanisms involved in $\mathrm{H} 2 \mathrm{r}$ uncoupling have been studied in different systems. In COS-7 transfected cells, GRK2 and GRK3 phosphorylation mediates H2r desensitization (Shayo et al., 2001).

The aim of the present study was to investigate the participation of GRK2 in H2r desensitization in U-937 cells and to elucidate whether the lack of cell differentiation after treatment with $\mathrm{H} 2$ agonist was caused by rapid H2r desensitization. Results demonstrate that the attenuation of GRK2 levels by antisense cDNA reduces the desensitization of the $\mathrm{H} 2 \mathrm{r}$ in U-937 cells and allows the $\mathrm{H} 2$ agonist to induce markers of cell maturation.

\section{Materials and Methods}

Materials. Restriction enzymes and DNA ligase were purchased from New England Biolabs, Inc. (Beverly, MA). Cell culture medium, DEAE-dextran, 3-isobutyl-1-methylxanthine (IBMX), cAMP, dbcAMP, forskolin, isoproterenol, Fura 2 acetoxymethyl ester (AM), bovine serum albumin (BSA), C5a, Tween-20, protease inhibitors, and phosphatase inhibitors, were obtained from Sigma Chemical Co. (St. Louis, MO). Fetal calf serum was obtained from Invitrogen (Carlsbad, CA). Amthamine and 6[2-(4-imidazolyl)ethylamino]- $N$-(4trifluoromethylphenyl)heptanecarboxamide were from Tocris Cookson Inc. (Ballwin, MO). $N$-[2-( $p$-Bromocinnamylamino)ethyl]-5isoquinolinesulfonamide $2 \mathrm{HCl}(\mathrm{H}-89)$ was obtained from Calbiochem (La Jolla, CA). $\left[{ }^{3} \mathrm{H}\right] \mathrm{cAMP}$ and $\left[{ }^{3} \mathrm{H}\right]$ tiotidine were purchased from PerkinElmer Life Sciences (Boston, MA) and $\left[{ }^{32} \mathrm{P}\right]$ orthophosphate was from Amersham Biosciences (Little Chalfont, Buckinghamshire, UK). All other chemicals were of analytical grade.

Plasmid Constructions. To prepare the GRK2 antisense construct, pBluescript was used to isolate the EcoRI/NheI fragment containing the GRK2 bovine cDNA. The eukaryotic expression vector pCEFL-HA (Teramoto et al., 1996) was cut with restriction endonucleases NheI and EcoRI. The larger NheI/EcoRI fragment from the plasmid was isolated and ligated to the fragment containing the GRK2 bovine cDNA. The result was a plasmid containing the GRK2 cDNA in reverse orientation with respect to the $\mathrm{pCEFL}-\mathrm{HA}$ promoter (pCEFL-HA-antiGRK2). The orientation was confirmed by digestion with $K p n I$ and $E c o$ RI, giving fragments of 7.7 and 0.3 kilobase pairs. GRK2 and -3 cDNAs were subcloned into the pCEFL vector (pCEFLGRK2 and -3). Plasmid purification was performed using reagents from QIAGEN (Valencia, CA) according to the manufacturer's instructions.

Cell Culture. U-937 and COS-7 cells were cultured at $37^{\circ} \mathrm{C}$ in a humidified atmosphere with $5 \% \mathrm{CO}_{2}$ in RPMI 1640 medium and Dulbecco's modified Eagle's medium, respectively, supplemented with $10 \%$ fetal calf serum and $50 \mu \mathrm{g} / \mathrm{ml}$ gentamicin.

Transient Transfection of COS-7 Cells. Transient transfection was performed by the DEAE-dextran technique as reported previously (Shayo et al., 2001). For GRK Western blotting, COS-7 cells were plated in $35-\mathrm{mm}$ dishes and transfected at $80 \%$ confluence using $1 \mu \mathrm{g}$ of each indicated plasmid. For the immunoprecipitation assay, cells were plated in 100-mm dishes and transfected with $2 \mu \mathrm{g}$ of each construct. The total amount of plasmids was equaled with vector alone. All assays were performed $48 \mathrm{~h}$ after transfection.

Stable Transfection of U-937 Cells. Cells were harvested by centrifugation from cultures in exponential growth phase, washed once in phosphate-buffered saline (PBS), and resuspended at $10^{6}$ cells $/ \mathrm{ml}$ in fresh RPMI medium on ice. pCEFL-HA-antiGRK2 $(10 \mu \mathrm{g})$ linearized with SalI or pCEFL-HA linearized with EcoRI was added to cell suspension $(400 \mu \mathrm{l})$ and kept $5 \mathrm{~min}$ on ice. Cells and DNA were then subjected to a pulse of $150 \mathrm{~V}$ at a capacitance of $250 \mu \mathrm{F}$ using a Gene Pulser (Bio-Rad, Hercules, CA). Cells were returned to ice for $5 \mathrm{~min}$ and incubated in a nonselective medium overnight. Cells were then plated in a 96-well culture plate in RPMI medium containing $0.8 \mathrm{mg} / \mathrm{ml} \mathrm{G}-418$. After 2 to 3 weeks, the surviving clones were amplified.

Western Blots. Cells were lysed in sample buffer $(50 \mathrm{mM}$ Tris$\mathrm{HCl}, \mathrm{pH}$ 6.8, 2\% SDS, $100 \mathrm{mM}$ 2-mercaptoethanol, 10\% glycerol, and $0.05 \%$ bromphenol blue), and sonicated to shear DNA. Samples were boiled for $5 \mathrm{~min}$, and aliquots were subjected to electrophoresis in $12 \%$ SDS-polyacrylamide gels and transferred to nitrocellulose membranes. The residual binding sites were blocked with $5 \%$ nonfat powdered milk in PBS containing $0.05 \%$ Tween-20, and membranes were incubated with $1 \mu \mathrm{g} / \mathrm{ml}$ of anti-GRK2, -3, or c-Fos rabbit antibody (Santa Cruz Biotechnology, Santa Cruz, CA), in PBS containing $0.05 \%$ Tween-20. All subsequent washes were performed with the same buffer. Reactivity was developed using an anti-rabbit polyclonal antibody linked to horseradish peroxidase and enhanced chemiluminescence reagents, according to the manufacturer's instructions (Amersham Biosciences).

Phosphorylation Assays. Transfected cells were preincubated for $1 \mathrm{~h}$ at $37^{\circ} \mathrm{C}$ in phosphate-free Dulbecco's modified Eagle's medium and labeled $3 \mathrm{~h}$ with $100 \mu \mathrm{Ci} / \mathrm{ml}$ of ${ }^{32} \mathrm{P}_{\mathrm{i}}$ at $37^{\circ} \mathrm{C}$ in fresh medium. H2 agonist was applied as indicated in figure legends. The reaction was stopped by placing the cells at $4^{\circ} \mathrm{C}$ and washing twice with ice-cold PBS, followed by the addition of $1 \mathrm{ml} /$ plate of immunoprecipitation buffer (150 mM NaCl, $50 \mathrm{mM}$ Tris-HCl, $\mathrm{pH} 8,1 \%$ Nonidet P-40, 0.1\% SDS, $0.2 \mathrm{mM}$ EDTA, $10 \mathrm{mM} \mathrm{NaF}, 1 \mathrm{mM}$ sodium vanadate, $1 \mathrm{mM}$ phenylmethylsulfonyl fluoride, $5 \mu \mathrm{M}$ aprotinin, 10 $\mu \mathrm{M}$ leupeptin, and $5 \mu \mathrm{M}$ pepstatin). Lysed cells were centrifuged for $20 \mathrm{~min}$ at $12,000 \mathrm{~g}$ at $4^{\circ} \mathrm{C}$. The epitope-tagged $\mathrm{H} 2$ histamine receptor was immunoprecipitated from the supernatant by a $1 \mathrm{~h}$ incubation with the specific anti-HA antibody (Babco, Richmond, CA) at $4^{\circ} \mathrm{C}$. Immunocomplexes were recovered with the aid of Protein A/G- 
Sepharose (Santa Cruz Biotechnology) and washed five times with ice-cold immunoprecipitation buffer. Complexes were then dissociated by heating to $65^{\circ} \mathrm{C}$ for $10 \mathrm{~min}$ in sample buffer and separated by $12 \%$ SDS-polyacrylamide gel electrophoresis. Gels were dried and exposed to AGFA Curix RP1 films (Agfa Gevaert, Leverkusen, Germany). ${ }^{32}$ P-labeling was quantified with the use of the Scion Image software (Scion Corporation, Frederick, MD).

cAMP Assay. Cells were resuspended in Hanks' solution supplemented or not with $1 \mathrm{mM}$ IBMX, at a density of $10^{6}$ cells $/ \mathrm{ml}$, preincubated $3 \mathrm{~min}$ at $37^{\circ} \mathrm{C}$, and exposed for different periods of time to different chemicals at the indicated concentrations. The reaction was stopped by ethanol addition and centrifuged $10 \mathrm{~min}$ at $3000 \mathrm{~g}$. The ethanol phase was then dried and resuspended in $50 \mathrm{mM}$ Tris- $\mathrm{HCl}$, $\mathrm{pH} 7.4$, and $0.1 \%$ BSA.

For the desensitization assay, pretreatment of cells with amthamine was performed in RPMI 1640 medium at $37^{\circ} \mathrm{C}$ in a $5 \%$ $\mathrm{CO}_{2}$ humidified atmosphere. Cells were exposed to $10 \mu \mathrm{M} \mathrm{H}$ agonists (maximal response) for periods ranging from $1 \mathrm{~min}$ to $3 \mathrm{~h}$, in the absence of IBMX. Cells were then washed and resuspended in Hanks' solution containing $1 \mathrm{mM}$ IBMX at a density of $10^{6}$ cells $/ \mathrm{ml}$ and exposed for $10 \mathrm{~min}$ to $10 \mu \mathrm{M} \mathrm{H}_{2}$ agonists to determine whether $\mathrm{AC}$ could still generate cAMP.

cAMP content was determined by means of competition with $\left[{ }^{3} \mathrm{H}\right] \mathrm{cAMP}$ for PKA, as described previously (Davio et al., 1995b). cAMP production is expressed as picomoles of cAMP produced per $10^{6}$ cells.

Radioligand Binding Assay. Triplicate assays were performed in polyethylene tubes in $50 \mathrm{mM}$ Tris-HCl, $\mathrm{pH}$ 7.4. For saturation studies, increasing concentrations of $\left[{ }^{3} \mathrm{H}\right]$ tiotidine were incubated with $10^{6}$ cells/tube, in the absence or presence of $1 \mu \mathrm{M}$ tiotidine, in a total volume of $200 \mu \mathrm{l}$. After $40 \mathrm{~min}$ at $4^{\circ} \mathrm{C}$, incubation was stopped by dilution with $3 \mathrm{ml}$ of ice-cold $50 \mathrm{mM}$ Tris-HCl, $\mathrm{pH}$ 7.4, and rapid filtration under reduced pressure onto Whatman GF/B glass-fibers filters was performed, followed by three washes with $3 \mathrm{ml}$ of ice-cold buffer. Experiments on intact cells were carried out at $4^{\circ} \mathrm{C}$ to avoid internalization of the ligand. Kinetic studies performed with $2 \mathrm{nM}$ $\left[{ }^{3} \mathrm{H}\right]$ tiotidine at $4^{\circ} \mathrm{C}$ showed that equilibrium was reached after 30 min and persisted for $4 \mathrm{~h}$ (data not shown).

Intracellular $\mathbf{C a}^{2+}$ Measurements. Fura 2-AM was used as a fluorescent indicator. Cells from each experimental group were washed, resuspended, and incubated in a buffered saline solution (BSS; $140 \mathrm{mM} \mathrm{NaCl}, 3.9 \mathrm{mM} \mathrm{KCl}, 0.7 \mathrm{mM} \mathrm{KH} \mathrm{PO}_{4}, 0.5 \mathrm{mM}$ $\mathrm{Na}_{2} \mathrm{HPO}_{4} 1 \mathrm{mM} \mathrm{CaCl}, 0.5 \mathrm{mM} \mathrm{MgCl}$, and $20 \mathrm{mM}$ HEPES, $\mathrm{pH}$ 7.5) in the presence of $2 \mu \mathrm{M}$ Fura 2-AM, $10 \mathrm{mM}$ glucose, and $0.1 \%$ BSA. Cells were incubated for $30 \mathrm{~min}$ at $37^{\circ} \mathrm{C}$ in an atmosphere of $5 \% \mathrm{CO}_{2}$, by which time Fura 2 was trapped intracellularly by esterase cleavage. Cells were then washed twice in BSS without Fura 2-AM, and brought to a density of $2 \times 10^{6}$ cells $/ \mathrm{ml}$ of BSS. Fluorescence was measured in a spectrofluorometer (Jasco, Tokyo, Japan), equipped with the CA-261 accessory (to measure $\mathrm{Ca}^{2+}$ with continuous stirring), the thermostat adjusted to $37^{\circ} \mathrm{C}$, and an injection chamber. Intracellular $\mathrm{Ca}^{2+}\left(\left[\mathrm{Ca}^{2+}\right] \mathrm{i}\right)$ levels were registered every second by exposure to alternating 340- and 380-nm light beams, and the intensity of light emission at $505 \mathrm{~nm}$ was measured. In this way, light intensities and their ratio (F340/F380) were tracked. Different agents were injected $(5 \mu \mathrm{l})$ into the chamber as a 100 -fold concentrated solution without interrupting recording. The preparation was calibrated by determining maximal fluorescence induced by $0.1 \%$ Triton X-100 and minimal fluorescence in the presence of $6 \mathrm{mM}$ EGTA, pH 8.3. $\left[\mathrm{Ca}^{2+}\right]$ i was calculated according to Grynkiewicz et al. (1985).

\section{Results}

Functionality of GRK2 Antisense Construct. As an initial step, the GRK2 antisense cDNA, constructed as detailed under Materials and Methods, was assayed for its capability to specifically inhibit the production of GRK2 protein in COS-7 transfected cells, because GRK2 and GRK3 share $72.5 \%$ of their sequence. COS-7 cells were transiently cotransfected with GRK2 antisense and GRK2 or GRK3 sense expression vectors, alternatively. After $48 \mathrm{~h}$, Western blotting indicated that the antisense construct reduced GRK2 protein levels but did not interfere with GRK3 levels (Fig. 1A). H2r phosphorylation after H2 agonist stimulus was examined to determine whether the observed reductions in GRK2 expression were sufficient to produce a significant reduction in GRK2 activity. Cells transfected with the tagged receptor (HA-H2r) and GRK2 antisense expression vector reduced both HA-H2r phosphorylation induced by endogenous GRKs and the enhanced phosphorylation obtained after GRK2 transfection (Fig. 1B).

Creation of U-937 Cell Lines Containing GRK2 Antisense. The antisense-GRK2 construction was used to stably transfect U-937 cell line. Three clones resistant to G-418 were obtained: D5, A2, and H3. As a control, U-937 cells were transfected with the vector alone, resulting in the D2 clone.

The D5 and A2 clones were identified as having reduced levels of GRK2 expression compared with U-937 or D2 cells. Densitometry studies estimated 50 and $45 \%$ reductions in GRK2 levels for D5 and A2, respectively, whereas no modifications were observed in H3 cells (Fig. 2). Finally, all clones proved to express identical GRK3 and GRK6 levels (data not shown).

cAMP Response in GRK2-Antisense Clones. The consequence of GRK2 level reduction on receptor-mediated cAMP production and accumulation induced by the $\mathrm{H} 2$ agonist was examined in D5 cells (cells with lower GRK2 levels). In amthamine dose-response experiments, D5 cells' maximal response was higher than in control cells (U-937 and D2).
A
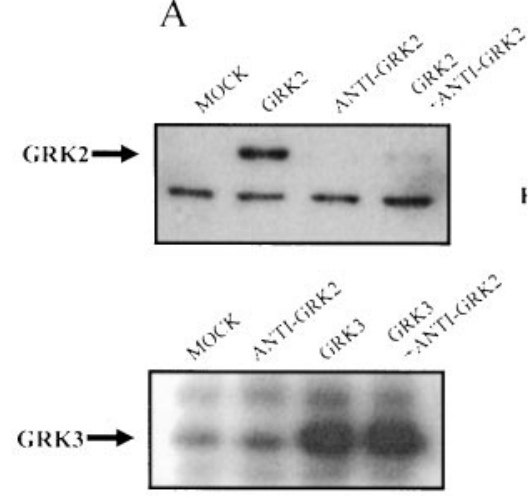

B
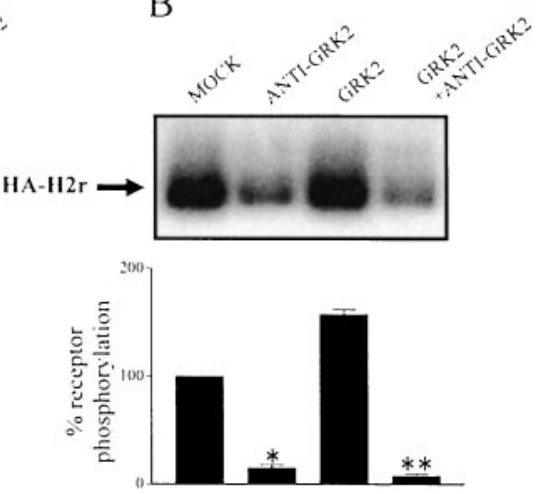

Fig. 1. Specific reductions of GRK2 levels and activity in COS-7 cells. A, COS-7 cells were transfected with pCEFL (MOCK), pCEFL-GRK2, -3, and GRK2 antisense (ANTI) as indicated $48 \mathrm{~h}$ after transfection. Cells were lysed, subjected to $12 \%$ SDS-polyacrylamide gel electrophoresis, followed by Western blotting with polyclonal purified rabbit sera against GRK2 or GRK3. B, COS-7 cells were transfected with pCEFL-HA-H2r and pCEFL (MOCK), pCEFLGRK2, and GRK2 antisense (ANTI), as indicated. After ${ }^{32} \mathrm{P}$ incorporation, cells were stimulated for $10 \mathrm{~min}$ with $10 \mu \mathrm{M}$ amthamine. HA-H2r phosphorylation was determined as described under Materials and Methods. ${ }^{32} \mathrm{P}$ labeling was quantified using the Scion Image program. Data were calculated as the means \pm S.E.M. of three experiments. *, $p<$ 0.01 compared with HA-H2r-transfected cells. ${ }^{* *}, p<0.001$ compared with HA-H2r and GRK2-transfected cells. 

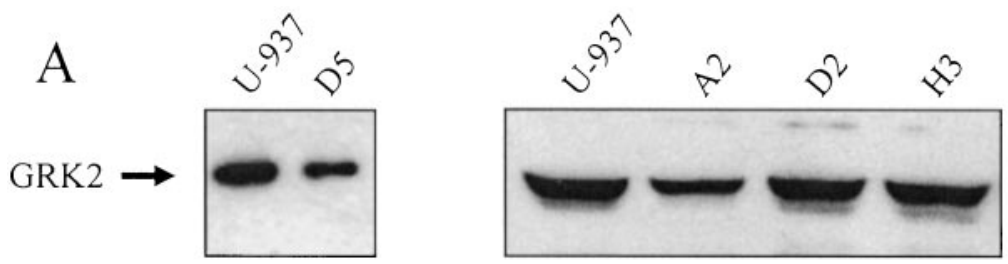

B
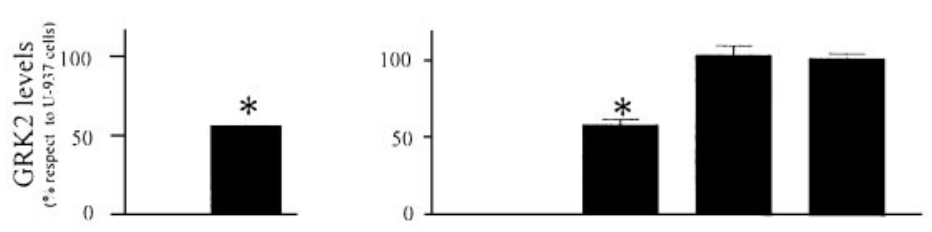

Fig. 2. Effect of GRK2 antisense expression on GRK2 levels. A, whole-cell lysates of the different clones were subjected to $12 \%$ SDS-polyacrylamide gel electrophoresis, followed by Western blotting with polyclonal purified rabbit sera against GRK2. B, densitometric analysis obtained with the Scion Image program. Data were calculated as the means \pm S.E.M. of three experiments. ${ }^{*}, p<0.01$ compared with U-937 cells.
Similar results were obtained for the A2 but not for the H3 clone, indicating that GRK2 reduction, not clonal variations, caused these increases. This higher response was attributable to an event upstream of AC activation, because in forskolin dose-response experiments, no differences were observed for D5 compared with U-937 cells (Fig. 3; Table 1).

For the evaluation of cAMP accumulation kinetics in D5 cells, D5 and control cells were treated with $10 \mu \mathrm{M}$ amthamine for different periods of time in presence of IBMX. The cAMP response reached in each time by D5 cells was approximately 2-fold the U-937 levels. After a 60-min stimulus, when maximal response was reached, A2 cAMP levels were similar to those in D5 cells, whereas the H3 and D2 clones behaved as did U-937 (Fig. 4).

To corroborate the results mentioned above, a desensitization experiment, in which cells exposed to $10 \mu \mathrm{M}$ amthamine for different periods of time were rechallenged with the same agent to determine the system capability to still generate cAMP, was performed. The U-937 desensitization curve was coincident with the one previously reported by our group (Lemos Legnazzi et al., 2000), showing a half-maximal desensitization time of $11.7 \pm 1.6$ min (mean \pm S.E.M., $n=4)$. The reduction of GRK2 levels significantly modified the desensitization curve, because D5 cells showed a higher half-

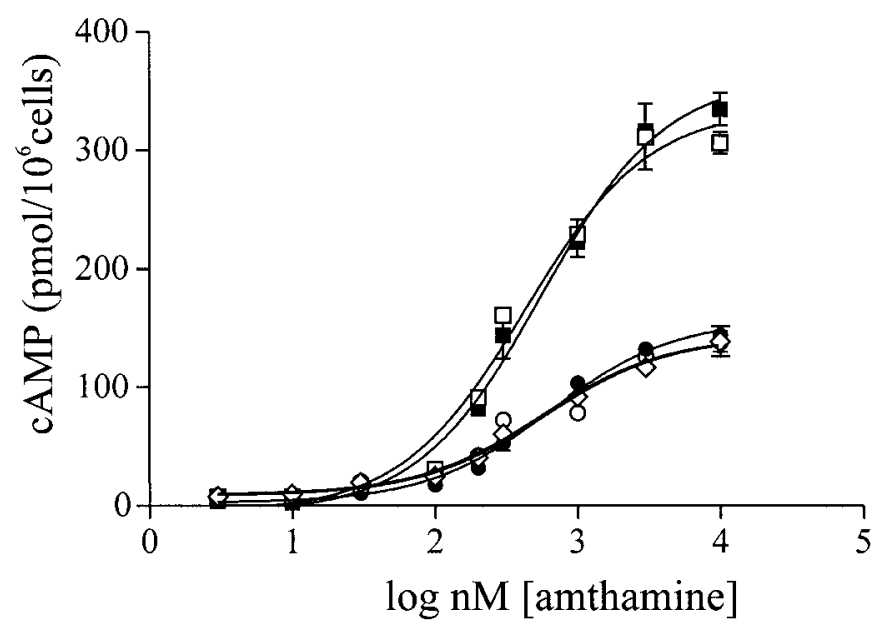

Fig. 3. Effect of GRK2 antisense expression on dose-response curves for cAMP production. U-937 $(\bullet), \mathrm{D} 2(\bigcirc)$, A2 $(\square)$, D5 $(\square)$, and H3 $(\diamond)$ cells were incubated for 9 min with increasing concentrations of amthamine at $37^{\circ} \mathrm{C}$ in the presence of $1 \mathrm{mM}$ IBMX, and cAMP levels determined. Data were calculated as the means \pm S.D. of assay triplicates. Similar results were obtained in at least three independent experiments. maximal desensitization time of $51.7 \pm 5.3$ min (mean \pm S.E.M., $n=3$ ), and similar results were obtained for A2 cells. D2 and H3 did not significantly modify the half-maximal desensitization time compared with U-937 (Fig. 5A; Table 2).

To elucidate whether the remaining H2r desensitization observed in D5 and A2 clones was caused by a heterologous component, such as H2r desensitization by PKA phosphorylation, desensitization assays in the presence of PKA inhibitor (H-89) were carried out. On the other hand, taking into account its known desensitization by PKA (Lohse et al., 1990), $\beta_{2}$ adrenergic receptor response was evaluated after H2 agonist pretreatment. The desensitization achieved by $\mathrm{H} 2$ agonist pretreatment was not prevented by H-89 in either U-937 or D5 cell lines. When desensitized cells were challenged with isoproterenol, the response evoked was similar to that for nonpretreated cells (Fig. 5B). Overall, these results indicate that a heterologous PKA-dependent component is not involved in the remaining $\mathrm{H} 2 \mathrm{r}$ desensitization.

Because cAMP determinations in the above experiments were performed in the presence of IBMX (a phosphodiesterase inhibitor), and in an attempt to determine the cAMP levels resulting from the production-degradation balance, the time course of cAMP accumulation in the absence of IBMX was determined. Results indicated that D5 and A2 cells show higher cAMP levels with a slow response decay phase and superior residual response $2 \mathrm{~h}$ after stimulus than U-937, D2, or H3 cells (Fig. 6).

H2 Receptors in U-937 and GRK2-Antisense Clones. To further support the hypothesis that the differences in cAMP response were caused by the different levels of GRK2 and not by an increase in receptor numbers in D5 and A2 cells, $\left[{ }^{3} \mathrm{H}\right]$ tiotidine binding experiments were carried out. Saturation analysis using intact cells revealed that D5 and A2 clones had a significantly lower receptor number than the other clones (U-937, D2, and H3), despite their increased cAMP response. In addition, there were no significant differences among $K_{\mathrm{d}}$ values (Fig. 7; Table 3).

Induction of Monocytic Maturation Markers in GRK2-Antisense Clones by H2 Agonist. In previous studies, we hypothesized that U-937 promonocytic cells were not capable of differentiating with $\mathrm{H} 2$ agonists because of the short H2r desensitization time (Shayo et al., 1997). Therefore, GRK2-antisense clones with a longer H2r desensitization time were analyzed for their capability to differentiate with amthamine. The sustained c-Fos expression in U-937 cells was associated with cell differentiation. In this way, 
TABLE 1

cAMP response in GRK2-antisense clones

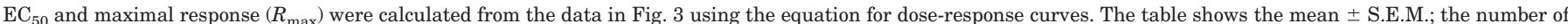

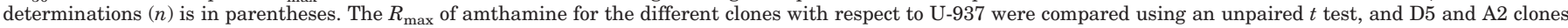
were found to be significantly different.

\begin{tabular}{|c|c|c|c|c|}
\hline & \multicolumn{2}{|c|}{ Amthamine } & \multicolumn{2}{|c|}{ Forskolin } \\
\hline & $\mathrm{EC}_{50}$ & $R_{\max }$ & $\mathrm{EC}_{50}$ & $R_{\max }$ \\
\hline & $n M$ & $\mathrm{pmol} / 10^{6}$ cells & $m M$ & $\mathrm{pmol} / 10^{6} \mathrm{cells}$ \\
\hline U-937 & $465 \pm 95(5)$ & $184 \pm 35(5)$ & $161 \pm 42(3)$ & $120 \pm 27(3)$ \\
\hline D2 & $562 \pm 97(3)$ & $143 \pm 26(3)$ & N.D. & N.D. \\
\hline $\mathrm{A} 2$ & $426 \pm 47(3)$ & $281 \pm 67(3)^{*}$ & N.D. & N.D. \\
\hline D5 & $472 \pm 67(3)$ & $292 \pm 38(3)^{*}$ & $121 \pm 37(3)$ & $116 \pm 22(3)$ \\
\hline H3 & $584 \pm 78(3)$ & $142 \pm 27(3)$ & N.D. & N.D. \\
\hline
\end{tabular}

N.D., not determined.

$*, p<0.01$.

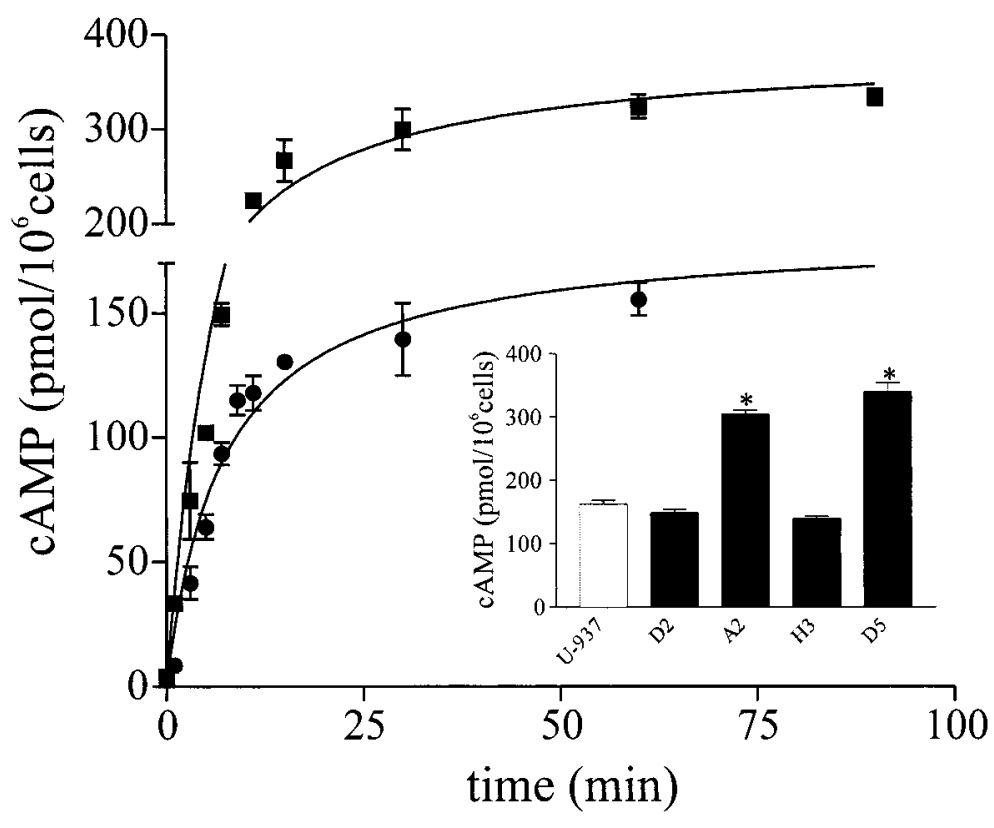

Fig. 4. Effect of GRK2 antisense expression on the time course of cAMP accumulation. U-937 ( ) and D5 ( $\mathbf{\square}$ cells were incubated for different periods of time with $10 \mu \mathrm{M}$ amthamine at $37^{\circ} \mathrm{C}$ in the presence of $1 \mathrm{mM}$ IBMX, and cAMP levels were determined. Data were calculated as the means \pm S.D. of assay triplicates. Similar results were obtained in at least three independent experiments. Inset, D2, A2, and $\mathrm{H} 3$ cells were incubated for $60 \mathrm{~min}$ with $10 \mu \mathrm{M}$ amthamine at $37^{\circ} \mathrm{C}$ in the presence of $1 \mathrm{mM}$ IBMX, and cAMP levels were determined. Data were calculated as the means \pm S.E.M. of three independent experiments. *, $p<0.01$ compared with U-937 cells.

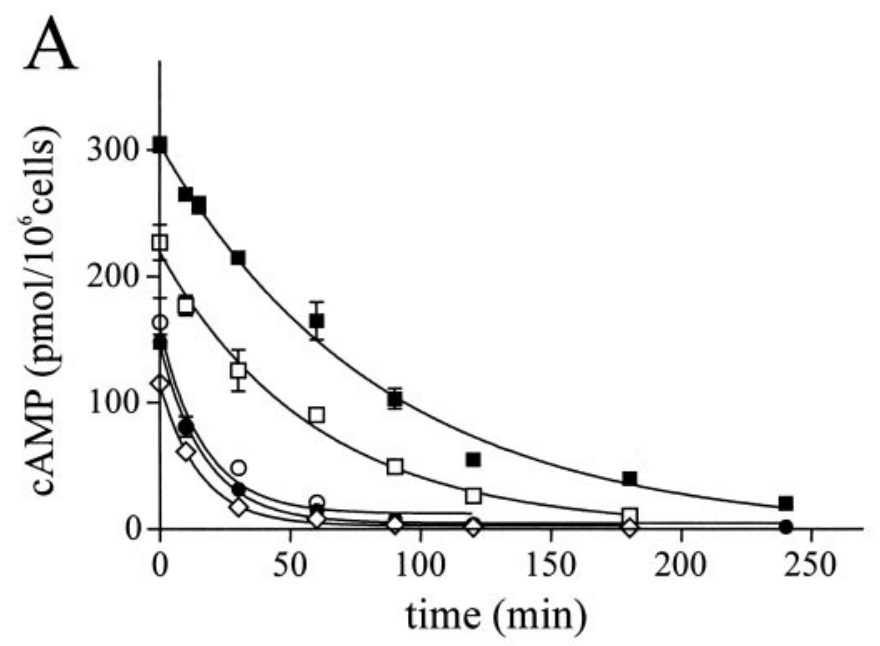

B

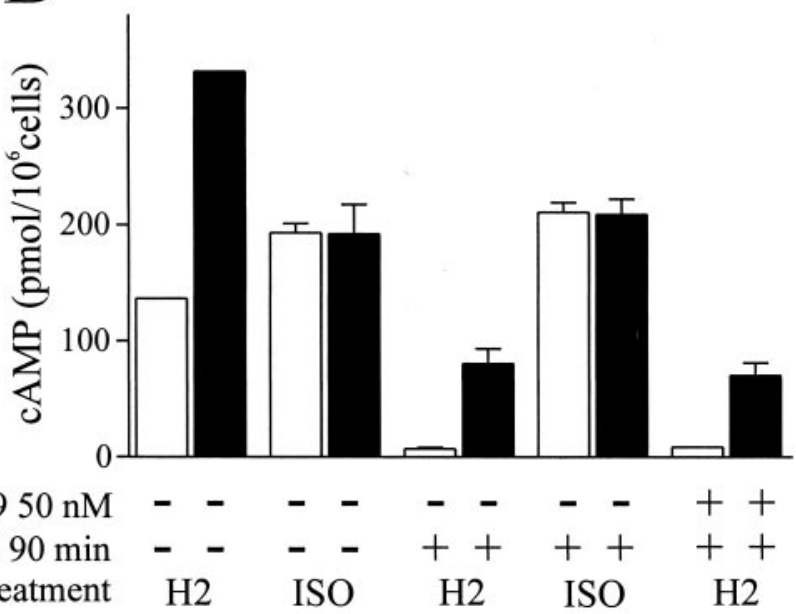

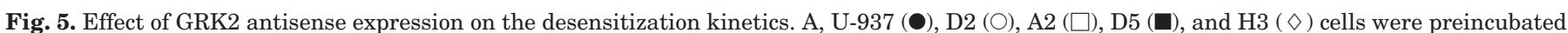
for different periods of time with $10 \mu \mathrm{M}$ amthamine, washed, and restimulated with $10 \mu \mathrm{M}$ amthamine in the presence of $1 \mathrm{mM}$ IBMX. cAMP production was determined as described under Materials and Methods. Data were calculated as the means \pm S.D. of assay triplicates. Similar results were obtained in at least three independent experiments. B, U-937 (open bars) and D5 (closed bars) cells were pretreated 30 min or not with $50 \mathrm{nM}$ $\mathrm{H}-89$ and exposed $90 \mathrm{~min}$ or not to $10 \mu \mathrm{M}$ amthamine. Cells were then washed and stimulated with $10 \mu \mathrm{M}$ amthamine or $1 \mu \mathrm{M}$ isoproterenol in the presence of $1 \mathrm{mM}$ IBMX. Data were calculated as the means \pm S.E.M. of three experiments. 
TABLE 2

Desensitization of GRK2-antisense clones

The apparent rate of desensitization was calculated from the data in Fig. 5A using the equation for monoexponential decay. The table shows the mean \pm S.E.M.; the number of determinations $(n)$ is in parentheses. The apparent rates of desensitization were compared with U-937 using an unpaired $t$ test, and the D5 and A2 clones were found to be significantly different.

\begin{tabular}{lc}
\hline Cell Clones & Half-Maximal Desensitization Time \\
\hline & $\min$ \\
U-937 & $11.7 \pm 1.6(4)$ \\
D2 & $11.8 \pm 1.5(3)$ \\
A2 & $40.8 \pm 5.3(3)^{*}$ \\
D5 & $51.7 \pm 5.3(3)^{*}$ \\
H3 & $10.5 \pm 1.2(3)$ \\
\hline
\end{tabular}

$*, p<0.01$

U-937 treatment with amthamine produced a transient increase in c-Fos levels. However, in D5 cells, amthamine treatment induced a sustained pattern of c-Fos expression similar to that of dbcAMP-treated U-937 cells (Fig. 8).

On the other hand, C5a receptor (CD88) expression was assayed as a differentiation marker. The C5a receptor is a GPCR associated with $\mathrm{Ca}^{2+}$ release from intracellular stores (Burg et al., 1996). No response was observed in D5 or in control cells (U-937 and D2) when cells were stimulated with C5a without agonist pretreatment; cells stimulated with 6[2(4-imidazolyl)ethylamino]- $N$-(4-trifluoromethylphenyl)heptanecarboxamide (H1 agonist), known to elevate $\left[\mathrm{Ca}^{2+}\right] \mathrm{l}$ levels, showed the typical spike, indicating that these cells were capable of evoking a $\mathrm{Ca}^{2+}$ response. After 2 days of $10 \mu \mathrm{M}$ amthamine treatment, a $\left[\mathrm{Ca}^{2+}\right]$ i spike was induced by $\mathrm{C} 5 \mathrm{a}$ in D5 cells, whereas no response was observed in control cells. Similar results were obtained for A2, the other clone with low GRK2 levels. As a control-differentiating stimulus, cells were treated 2 days with dbcAMP; after stimulation with C5a, a $\left[\mathrm{Ca}^{2+}\right]$ i spike was observed in all cell clones (Fig. 9).

\section{Discussion}

In a previous study, we showed that the human promonocytic cell line U-937 possesses histamine H2 receptors (Davio et al., 1995a). We also found that the H2 agonist induces homologous and GRK dependent desensitization of $\mathrm{H} 2$ recep- tors in U-937 cells (Shayo et al., 1997; Lemos Legnazzi et al., 2000).

Recently, we demonstrated that transient cotransfection of COS-7 cells with H2r and either GRK2 or GRK3, dampened the cAMP response after a subsequent $\mathrm{H} 2$ agonist treatment and involved H2r phosphorylation (Shayo et al., 2001). However, in the MKN-45 cell line, only GRK2 was described as responsible for the desensitization of H2r (Nakata et al., 1996). Because high levels of overexpressed proteins were reached in COS-7 cells for both receptors and GRKs, it is possible that, by mass action, even GRK subtypes with low affinity for the agonist-bound receptor may phosphorylate it in a heterologous system, although not under physiological conditions.

Antisense technology has been used to demonstrate the involvement of different GRKs in the desensitization of several receptors: GRK5 in the thyrotropin receptor (Nagayama et al., 1996), GRK2 in the A2 adenosine receptors (Willets et al., 1999), GRK2, -5 , and -6 in the follicle-stimulating hormone receptor (Troispoux et al., 1999), GRK4 in the metabotropic glutamate receptor 1 (Sallesse et al., 2000), and GRK6 in the calcitonin gene-related peptide (Aiyar et al., 2000). In this study, using this technology, we attempted to evaluate the role of GRK2 in H2r desensitization in U-937 cells. For this purpose, using stable transfection of a GRK2 full-length cDNA antisense construct, we were able to specifically reduce protein levels of GRK2 in U-937 cells, indicated by a marked reduction in GRK2 but not GRK3 levels in D5 and A2 cells (stably-transfected U-937 cells with the GRK2 antisense construct). We described previously that U-937 cells express GRK2, -3, and -6 (Lemos Legnazzi et al., 2000). GRK6, which shares lower sequence homology with GRK2 rather than GRK3, showed no modified levels in D5 and A2 cells (data not shown). We also obtained an H3 clone, resistant to G-418, but with no reduction in GRK2 levels, probably because of the lack of GRK2 antisense cDNA expression.

This decrease in GRK2 expression correlates with an increase of cAMP levels in response to different doses of $\mathrm{H} 2$ agonist, and with the different kinetics of cAMP production compared with control cells (U-937 and D2).

In dose-response experiments, although the maximal re-

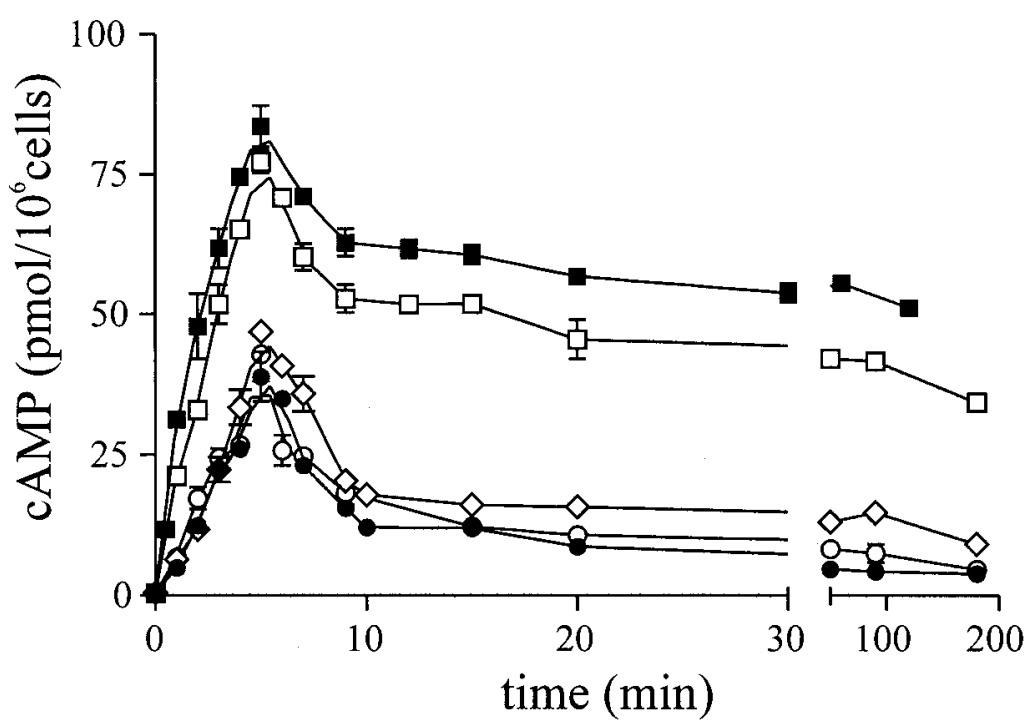

Fig. 6. Effect of GRK2 antisense on cAMP production in the absence of IBMX. U-937 $(\bullet), \mathrm{D} 2(\bigcirc), \mathrm{A} 2(\square)$, D5 ( $\square)$, and H3 ( $\diamond)$ cells were incubated for different periods of time with $10 \mu \mathrm{M}$ amthamine at $37^{\circ} \mathrm{C}$, and cAMP levels were determined. Data were calculated as the means \pm S.D. of assay triplicates. Similar results were obtained in at least three independent experiments. 


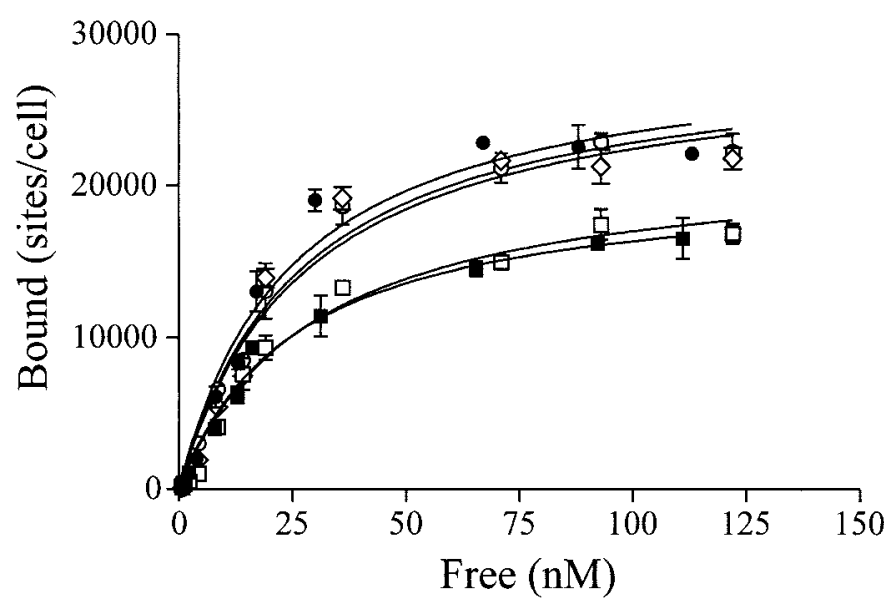

Fig. 7. $\left[{ }^{3} \mathrm{H}\right]$ Tiotidine binding assay. Saturation assays for $\left[{ }^{3} \mathrm{H}\right]$ tiotidine in U-937 $(\bullet)$, D2 $(\bigcirc)$, A2 $(\square)$, D5 $(\square)$, and H3 $(\diamond)$ cells. Data were calculated as the mean \pm S.D. of assay triplicates. Similar results were obtained in at least three independent experiments.

sponse was higher for D5 and A2 cells, the $\mathrm{EC}_{50}$ for amthamine was similar in all cell clones, indicating that the affinity of the agonist for the receptor was not modified. When stimulated with forskolin, the similar dose-response curves obtained for D5 and U-937 cells denoted that the modification observed in cAMP response in D5 cells was attributable to an event upstream of AC stimulation.

In time-course cAMP accumulation experiments and in the pretreatment assay, D5 and A2 cell desensitization seemed to be lower than in U-937, D2, or H3 cells, once again suggesting a role for GRK2 in this process. However, the desensitization was not completely blocked, possibly because of

TABLE 3

Binding of $\left[{ }^{3} \mathrm{H}\right]$ tiotidine

$K_{\mathrm{d}}$ and maximal bound $\left(B_{\max }\right)$ were calculated using the equation for one binding site. The table shows the mean \pm S.E.M.; the number of determination $(n)$ is in parentheses. $K_{\mathrm{d}}$ and $B_{\max }$ values were compared with U-937 using an unpaired $t$ test, and the D5 and A2 clones were found to be significantly different.

\begin{tabular}{lcc}
\hline \multicolumn{1}{c}{ Cell Clones } & $K_{\mathrm{d}}$ & $B_{\max }$ \\
\hline & $n M$ & sites $/$ cell \\
U-937 & $26 \pm 3(6)$ & $29,700 \pm 1,600(6)$ \\
D2 & $27 \pm 4(3)$ & $28,960 \pm 1,432(3)$ \\
A2 & $29 \pm 5(3)$ & $21,970 \pm 1,143(3)^{*}$ \\
D5 & $26 \pm 4(3)$ & $19,900 \pm 900(3)^{*}$ \\
H3 & $28 \pm 5(3)$ & $28,620 \pm 1,829(3)$ \\
\hline$*, p<0.01$. & &
\end{tabular}

remaining GRK2 levels, other GRKs such as GRK3 [as observed in COS-7 cells (Shayo et al., 2001)], or to an alternative mechanism not involving GRKs. The presence of a component of heterologous desensitization involving PKA can be ruled out, because in desensitization experiments, the presence of a PKA inhibitor did not modify cAMP levels, and amthamine-pretreated cells did not modify isoproterenol response. The time-course cAMP accumulation experiments in the absence of IBMX gave rise to higher levels of cAMP in D5 and A2 cells as well as in assays in the presence of IBMX and in desensitization experiments. These results rule out the possibility of a compensatory mechanism, tending to maintain the original cell cAMP levels in the clones, such as an increase in phosphodiesterase activity in the initial step of the response. An induction of phosphodiesterase activity was observed in U-937 cells after $4 \mathrm{~h}$ of $\mathrm{H} 2$ agonist treatment, which was not involved in the mechanism of rapid desensitization (Lemos Legnazzi et al., 2000).

Even though we suppose that the reduction in GRK2 expression was responsible for a higher cAMP response after stimulation with amthamine, we could not discard the possibility that D5 and A2 cells possessed an increased receptor number. Surprisingly, D5 and A2 clones showed a significant decrease in membrane receptor number with respect to native cells or to transfected cells with no regulation of GRK2 levels. Our findings in GRK2 antisense-expressing cells suggest that GRKs not only regulate receptor desensitization but also play a role in the steady-state level of receptor expression. A recent study in Chinese hamster ovary cells demonstrates that the loss in GRK2-phosphorylating activity seemed to correlate with an increase in calcitonin receptor numbers (Horie and Insel, 2000), in contrast to the results observed for $\mathrm{H} 2$ receptors in U-937 cells. This evidence suggests that GRKs can regulate GPCRs and that its expression could be negatively or positively influenced by GRK activity depending on the receptor and/or the cell type. These results open an interesting question concerning the regulation between kinases involved in receptor phosphorylation and membrane receptor expression.

In a recent report, we showed that forskolin induces U-937 cell differentiation through a sustained rise in cAMP levels, whereas histamine or $\mathrm{H} 2$ agonists, which increase cAMP levels with a short desensitization half-time, failed to promote differentiation (Brodsky et al., 1998). Here, we evaluated the capacity of an H2 agonist to differentiate GRK2

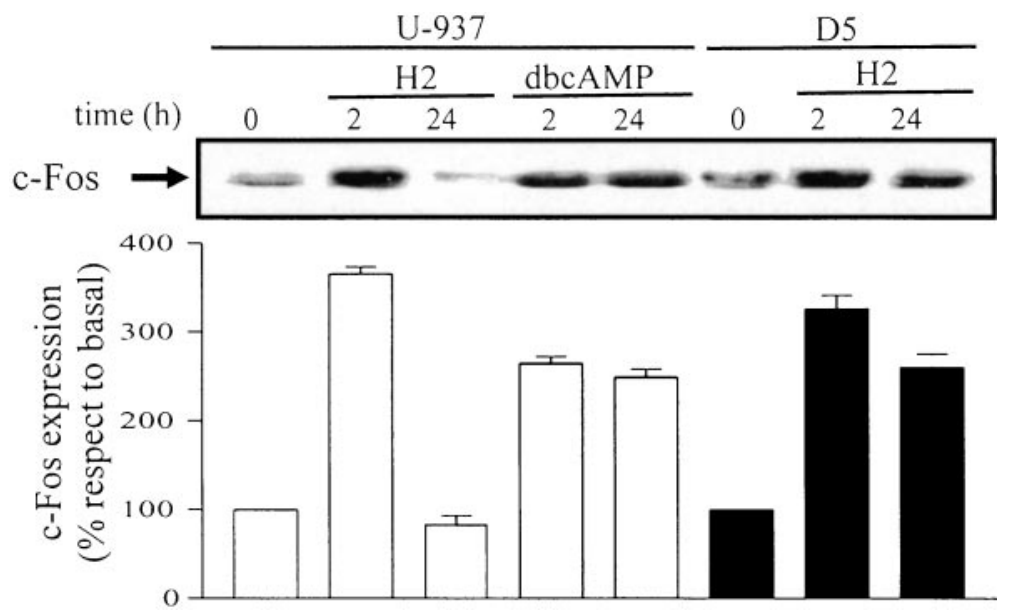

Fig. 8. c-Fos expression in U-937 and D5 cells. Top, cells were incubated with $10 \mu \mathrm{M}$ amthamine or $0.4 \mathrm{mM}$ dbcAMP for the indicated periods of time before harvesting, and lysed as described under Materials and Methods. Samples were subjected to $12 \%$ SDS-polyacrylamide gel electrophoresis, followed by Western blotting with polyclonal purified rabbit sera against c-Fos. Bottom, densitometric analysis obtained with the Scion Image program. Data were calculated as the means \pm S.E.M. of three experiments. 
antisense clones, which showed lower desensitization than U-937 cells.

In this study, the pattern of c-Fos expression and the induction of C5a receptor were evaluated as markers of cell maturation. Monocytic maturation in U-937 cells was associated with the sustained induction of c-fos gene expression by several differentiation agents including PMA (Liu and Wu, 1992) and dbcAMP (Shayo et al., 1997). When D5 cells were treated with $\mathrm{H} 2$ agonist, they showed a pattern of c-Fos expression similar to U-937 differentiated cells.

Concerning the chemoattractant C5a receptor, this receptor is up-regulated when cells are stimulated with differentiation agents (Burg et al., 1996). In accordance with this, H2 agonist-treated D5 and A2 cells, but not U-937 or D2 cells, induced cytosolic $\mathrm{Ca}^{2+}$ increases upon ligand activation, indicating the presence of the receptor in cells expressing GRK2 antisense cDNA. The stable induction of c-Fos levels and the expression of C5a receptors in the GRK2-attenuated cell lines treated with $\mathrm{H} 2$ agonists indicate induction of monocytic maturation.

Overall, reduction in GRK2 levels determined the higher and prolonged cAMP response mediated by $\mathrm{H} 2 \mathrm{r}$, because of lower receptor desensitization, which in turn allows amthamine-stimulated cell differentiation. These results establish an important correlation between duration and intensity of a signal and cellular response, showing that as a consequence of modulating the desensitization process, cells are able to switch from the proliferation to differentiation pathway, indicating that the desensitization mechanism is a key component of receptor signaling and not just the cause of the lack of response.

\section{Acknowledgments}

We are sincerely grateful to Dr. J. F. Benovic (Thomas Jefferson University, Philadelphia, PA) for the GRK2 and GRK3 cDNAs, and

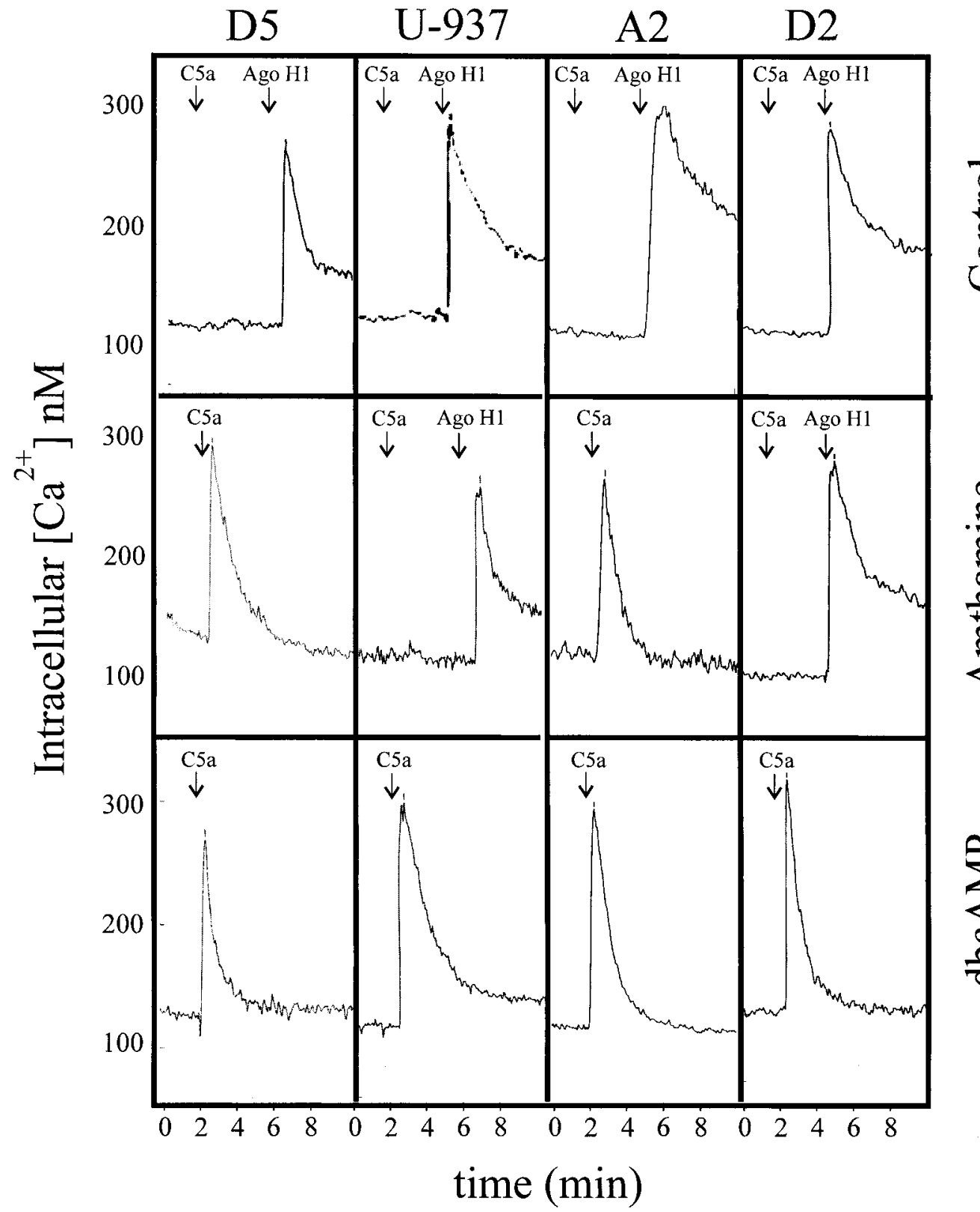

Fig. 9. Effect of $\mathrm{C} 5 \mathrm{a}$ on $\left[\mathrm{Ca}^{2+}\right] \mathrm{i}$ in amthamine- or dbcAMP-treated cells. U-937, D2, A2, and D5 cells were cultured for $48 \mathrm{~h}$ in the presence of $10 \mu \mathrm{M}$ amthamine or 0.4 $\mathrm{mM}$ dbcAMP. Control, nontreated cells. $\left[\mathrm{Ca}^{2+}\right] \mathrm{i}$ was determined as described under Materials and Methods. Arrows indicate the addition of $50 \mathrm{nM}$ C5a or $10 \mu \mathrm{M} \mathrm{H} 1$ agonist. Similar results were obtained in at least three independent experiments. 
to Dr. O. Coso (University of Buenos Aires, Buenos Aires, Argentina) for the expression vectors pCEFL and pCEFL-HA.

\section{References}

Aiyar N, Disa J, Dang K, Pronin AN, Benovic JL, and Nambi P (2000) Involvement of G protein-coupled receptor kinase-6 in desensitization of GPCR receptors. Eur J Pharmacol 403:1-7.

Brodsky A, Davio C, Shayo C, Lemos Legnazzi B, Barbosa M, Lardo M, Morelli A, Baldi A, Sanchez Avalos JC, and Rivera E (1998) Forskolin-induced U-937 cell line differentiation: a result of a sustained cAMP elevation. Eur J Pharmacol 350:121127.

Burg M, Martin U, Bock D, Rheinheimer C, Kohl J, Bautsch W, and Klos A (1996) Differential regulation of the C3a and C5a receptors (CD88) by IFN-gamma and PMA in U937 cells and related myeloblastic cell lines. J Immunol 157:5574-5581.

Chuang TT, Sallese M, Ambrosini G, Parruti G, and De Blasi A (1992) High expression of $\beta$-adrenergic receptor kinase in human peripheral blood leukocytes. Isoproterenol and platelet activating factor can induce kinase translocation. J Biol Chem 267:6886-6892.

Davio C, Baldi A, Shayo C, Brodsky A, Cricco G, Bergoc R, and Rivera E (1995a) H and $\mathrm{H}_{2}$ histamine receptors in histiocytic lymphoma cell line U937. Inflamm Res 44:S72-S73.

Davio C, Cricco G, Bergoc R, and Rivera E (1995b) $\mathrm{H}_{1}$ and $\mathrm{H}_{2}$ histamine receptors in $\mathrm{N}$-nitroso-N-methylurea (NMU)-induced carcinomas with atypical coupling to signal transducers. Biochem Pharmacol 50:91-96.

Dohlman HG, Thorner J, Caron MG, and Lefkowitz R (1991) Model systems for the study of seven-transmembrane segment receptors. Annu Rev Biochem 60:653688 .

Freedman N and Lefkowitz R (1996) Desensitization of G proteins coupled-receptors Recent Prog Horm Res 51:319-353.

Gavison R, Matzner Y, and Fibach E (1988) Differential induction of monocytic functions by dibutyryl cyclic AMP and retinoic acid in a human monoblast cell line U937. Isr J Med Sci 24:697-701.

Grynkiewicz G, Poenie M, and Tsien RY (1985) A new generation of $\mathrm{Ca}^{2+}$ indicators with greatly improved fluorescence properties. J Biol Chem 260:3440-3450.

Harris P and Ralph P (1985) Human leukemic models of myelomonocytic development: a review of the HL-60 and U937 cell lines. J Leukoc Biol 3:407-422.

Hill SJ (1990) Distribution, properties and functional characteristics of three classes of histamine receptor. Pharmacol Rev 42:45-83.

Hill SJ, Ganellin CR, Timmerman H, Schwartz JC, Shankley NP, Young JM, Schunack W, Levi R, and Hass HL (1997) International Union of Pharmacology. XIII. Classification of histamine receptors. Pharmacol Rev 49:253-278.

Horie K and Insel P (2000) Retrovirally mediated transfer of a G protein-coupled receptor kinase (GRK) dominant-negative mutant enhances endogenous calcitonin receptor signaling in Chinese Hamster ovary cells. J Biol Chem 275:29433-29440

Lemos Legnazzi B, Shayo C, Monczor F, Martín ME, Fernandez N, Brodsky A, Bald $A$, and Davio C (2000) Rapid desensitization and slow recovery of the cAMP response mediated by histamine $\mathrm{H}_{2}$ receptors in the U937 cell line. Biochem Pharmacol 60:159-166.

Leurs R, Smit MJ, and Timmerman H (1995) Molecular pharmacological aspects of histamine receptors. Pharmacol Ther 66:413-463.

Liu MY and Wu MC (1992) Induction of human monocyte cell line U937 differentiation and CSF-1 production by phorbol ester. Exp Hematol 20:974-979.

Lohse MJ, Benovic JL, Caron MG, and Lefkowitz RJ (1990) Multiple pathways of rapid $\beta 2$-adrenergic receptor desensitization. Delineation with specific inhibitors. J Biol Chem 265:3202-3211.
Moffett S, Rousseau G, Lagace M, and Bouvier M (2001) The palmitoylation state of the $\beta_{2}$-adrenergic receptor regulates the synergistic action of cyclic AMPdependent protein kinase and beta-adrenergic receptor kinase involved in its phosphorylation and desensitization. J Neurochem 76:269-79.

Nagayama Y, Tanaka K, Hara T, Namba H, Yamashita S, Taniyama K, and Niwa M (1996) Involvement of G protein-coupled receptor kinase 5 in homologous desensitization of the thyrotropin receptor. J Biol Chem 271:10143-10148.

Nakata H, Kinoshita Y, Kishi K, Fukuda H, Kawanami C, Matsushina Y, Asahara M, Okada A, Maekawa T, and Chiba T (1996) Involvement of $\beta$-adrenergic receptor kinase-1 in homologous desensitization of histamine $\mathrm{H}_{2}$ receptors in human gastric carcinoma cell line MKN-45. Digestion 57:406-410.

Palczewski K (1997) GTP binding protein coupled receptor kinases. Two mechanistic models. Eur J Biochem 248:261-269.

Pitcher JA, Freedman NJ, and Lefkowitz R (1998) G protein-coupled receptor kinases. Annu Rev Biochem 67:653-692.

Penn RB, Pronin AN, and Benovic JL (2000) Regulation of G protein-coupled receptor kinases. Trends Cardiovasc Med 10:81-89.

Post SR, Aguila-Buhain O, and Insel PA (1996) A key role for protein kinase A in homologous desensitization of the $\beta 2$-adrenergic receptor pathway in S49 lymphoma cells. $J$ Biol Chem 271:895-900.

Sallesse M, Salvatore L, D'Urbano E, Sala G, Storto M, Launey T, Nicoletti F, Knopfel T, and De Blasi A (2000) The G-protein-coupled receptor kinase GRK4 mediates homologous desensitization of metabotropic glutamate receptor 1 . FASEB J 14:2569-2580.

Shayo C, Davio C, Brodsky A, Mladovan A, Lemos Legnazzi B, Rivera E, and Baldi A (1997) Histamine modulates the expression of c-fos through cyclic AMP production via the $\mathrm{H}_{2}$ receptor in the human promonocytic cell line U-937. Mol Pharmacol 51:983-990.

Shayo C, Fernandez N, Lemos Legnazzi B, Monczor F, Mladovan A, Baldi A, and Davio C (2001) Histamine $\mathrm{H}_{2}$ receptor desensitization. Involvement of a select array of G protein-coupled receptor kinases (GRKs). Mol Pharmacol 60:10491056.

Tasaka K, Doi M, Nakaya N, and Mio M (1994) Reinforcement effect of histamine on the differentiation of murine myeloblast and promyelocytes: externalization of granulocyte colony-stimulating factor receptors induced by histamine. Mol Pharmacol 45:837-845.

Teramoto H, Crespo P, Coso OA, Igishi T, Xu N, and Gutkind JS (1996) The small GTP-binding protein rho activates c-Jun N-terminal kinases/stress-activated protein kinases in human kidney $293 \mathrm{~T}$ cells. Evidence for a Pak-independent signaling pathway. J Biol Chem 271:25731-25734.

Troispoux C, Guillou F, Elalouf JM, Firsov D, Iacovelli L, De Blassi A, Combarnous Y, and Reiter E (1999) Involvement of G protein-coupled receptor kinases and arrestins in desensitization to follicle-stimulating hormone action. Mol Endocrinol 13:1599-1614

Willets JM, Parent J, Benovic JL, and Kelly E (1999) Selective reduction in A2 adenosine receptor desensitization following antisense-induced suppression of $\mathrm{G}$ protein-coupled receptor kinase 2 expression. J Neurochem 73:1781-1789.

Zhu Y, Michalovich D, Wu H-L, Tan KB, Dytko GM, Mannan IJ, Boyce R, Alston J, Tierney LA, Li X, et al. (2001) Cloning, expression and pharmacological characterization of a novel human histamine receptor. Mol Pharmacol 59:434-441.

Address correspondence to: Carina Shayo, Ph.D., Institute of Biology and Experimental Medicine, Obligado 2490 (1428) Buenos Aires, Argentina. Email: cshayo@dna.uba.ar 